TEME, г. XLIII, бр. 3, јул - септембар 2019, стр. 681-694

Оригинални научни рад $\quad$ https://doi.org/10.22190/TEME190427042R

Примљено: 27. 4. 2019.

UDK 502.131.1:629.113

Ревидирана верзија: 8. 9. 2019.

Одобрено за штампу: 20. 10. 2019.

\title{
SUSTAINABLE DEVELOPMENT AS AN ADVANTAGE AND OBSTACLE FOR GLOBAL AUTOMOTIVE INDUSTRY ${ }^{a}$
}

\author{
Snežana Radukić, Dušan Perović*, Marija Petrović - Ranđelović \\ University of Niš, Faculty of Economics, Niš, Republic of Serbia \\ *bokaperovic@yahoo.com
}

\begin{abstract}
The paper investigates how business costs affect sustainable development policies of world's leading automotive producers. The core idea of the paper is to determine if business strategies have any effect on the three sustainable development pillars of world's leading automotive producers. The analysis involves the period of $2006-2017$ with world's top 15 automotive producers from three different continents. In this paper, the use of fixed effects model will help in analyzing automotive producer's efforts to achieve sustainable development goals with particular analysis of economic, environmental and social aspects of sustainable development in automotive industry. The result showed that economic pillar of sustainable development is more affected by business policy than other two, yet those not so strongly and significantly. This kind of research might contribute in conceptualizing new, efficient and effective business strategies for automotive producers in their attempt to achieve sustainable development goals as soon as possible.
\end{abstract}

Key words: sustainable development, automotive industry, environment, business strategies, corporate social responsibility.

\section{ОДРЖИВИ РАЗВОЈ КАО ПРЕДНОСТ И ПРЕПРЕКА ЗА ГЛОБАЛНУ АУТО-ИНДУСТРИЈУ}

\footnotetext{
Апстракт

У раду је истражено како трошкови пословања утичу на политике одрживог развоја највећих светских произвођача аутомобила. Основна идеја је да се утврди да ли и на који начин трошкови пословања утичу на три стуба одрживог развоја водећих светских произвођача аутомобила. Анализом је обухваћено 15 највећих произвођача аутомобила са три различита континента у периоду 2006-2017. У раду

${ }^{a}$ The paper presents a research within the project number 44007 supported by the Ministry of Education, Science and Technological Development of the Republic of Serbia.
} 
је коришћен модел регресионе анализе са фиксним ефектима како би се анализирали напори водећих произвођача аутомобила да остваре циљеве политике одрживог развоја. Анализом су обухваћени економски, еколошки и социјални стуб одрживог развоја унутар глобане ауто-индустрије. Резултати су показали да пословна политика произвођача аутомобила остварује знатно већи утицај на економски стуб одрживог развоја у односу на друга два стуба одрживог развоја. Ово истраживање пружиће помоћ произвођачима аутомобила у дефинисању нових, ефективних и ефикасних пословних стратегија којима би у великој мери били уважени циљеви одрживог развоја.

Кључне речи: одрживи развој, аутомобилска индустрија, заштита животне средине, пословне стратегије, друштвено одговорно пословање.

\section{INTRODUCTION}

Heavy use of fossil fuels carry a portion of responsibility in increasing global level of pollution, since the vast majority of cars still use fossil fuels, and cars are recognized as "critical sources of pollution". This happened due to uncontrolled increase in the number of vehicles over last 30 years, because higher economic growth brought a need for connecting places, and for achieving this goal more cars were produced. In many areas, car emissions have become a dominant source of air pollutants, including carbon monoxide $(\mathrm{CO})$, carbon dioxide $\left(\mathrm{CO}_{2}\right)$, volatile organic compounds (VOCs), hydrocarbons (HCs), nitrogen oxides $\left(\mathrm{NO}_{\mathrm{x}}\right)$ and particulate matter (PM) (Transportation Research Board, 2002). The increasing severity and duration of traffic congestion have a potential to continue with pollutant emissions and degradation of air, especially in areas near highways and dense roads. These emissions contribute to risks of morbidity and mortality for drivers, commuters and individuals living near roadways, as shown by epidemiological studies, evaluations of proposed vehicle emission standards, and environmental impact assessments for specific road projects (Health Effect Institute, 2010). At this point we have in view what level of pollution would be in the context of a higher volume of nixes, which among other issues, resulted in an extremely increased greenhouse effect, melting of glaciers and soil pollution by nitrates used in agricultural fields (Bostan et al. 2016).

Command and control regulation was the first step in changing habits of automotive producers through implementation of legally established standards, whose purpose is to create obvious improvements in environmental quality (Balkyte and Tvaronavičiene, 2010; Zanello et al, 2016). Authorities required automotive producers to respect environment, emission, production and other kinds of standards in order to reduce the use of technology that pollutes the environment and to gradually shift towards more sustainable technologies. In the case of automotive industry, implementing command and control regulation is not enough to achieve environmental goals, and because of that market-based regulation needs to become part of an overall environmental policy. Besides adequate 
procurement, reporting information on sustainability adds value to an organization and, in addition, it represents a useful instrument in developing a sustainable marketing strategy (Calu et al. 2015).

The structure of this paper comprises, besides introduction and conclusion, three more parts. The first part presents brief literature review of relation between automotive industry and sustainable development process, with clear emphasize on some results of sustainable development activities in automotive industry. The second and the third parts contain statistical analysis of sustainable development processes in global automotive industry. By analyzing several variables of sustainability related activities, that are common for all automotive producers, it was revealed if those activities really provide any viable results.

\section{LITERATURE REVIEW}

Wells (2004) analyzed integration between economic, environmental and social area in automotive industry. Analysis showed that sustainability is not a 'bolt on' addition, but an issue that goes to the heart of the structure and conduct of business. Mayyas et al. (2012) emphasized the importance of designing and producing sustainable cars with frequent changes in fuel price and raising environmental awareness. Authors suggest that automotive producers should rely on several approaches, if they want to achieve good results based both on healthy economics and the environment. These approaches and methods include: life - cycle assessment, the end-of-life perspective, the design for $\mathrm{X}$, the light weight engineering and material selection studies. Hashmi and Van Biesebroeck (2016) provided an interesting study about the equilibrium relationship between market structure and innovation in global automotive industry. In this case, equilibrium innovation is defined as a function of market structure; the vector of quality levels of all active automotive companies and the cost of R\&D.

Kushwaha and Sharma (2015) discovered strong relationship between automobile producers and global emission of $\mathrm{CO}_{2}$. Many automotive producers face dual pressure, one from the government towards $\mathrm{CO}_{2}$ emissions and the other from cost controlling and a company performance. Lee (2011) found that green way of doing business has statistically positive effects on a performance of a company, so investing in innovation and transformational leadership needs to be top priority for automotive producers, if they want to improve overall sustainability results. Bunzel and Runhau (2014) analyzed potential drivers of sustainability in the automotive industry with focus on original equipment manufacturers. For this kind of analysis authors have used Porter's Five Force analysis and discovered that vertical competition will have the greatest impact on producer's decision to continue with sustainable activities. Hahn et al. (2009) brought analysis about creating sustainable value by global automotive producers. Automotive producers create positive (or negative) sustainable value if they earn a higher (or lower) 
return than their industry peers with their available economic, environmental and social resources.

Juniarty and Ismael (2015) move sustainability to SME (small and medium enterprises) in Indonesian automotive component industry, in order to see how changes in automotive industry affect accompanying industries. Research showed that water consumption, waste management and noise and emission management, have very strong impact on automotive component industry in Indonesia, which represents a step forward in improving sustainability activities in Indonesia. Nakamichi et al. (2016) analyzed supply chain in Thailand automotive industry and found that lack of proper environmental model creates more trouble and costs to domestic automotive industry. With higher $\mathrm{CO}_{2}$ emissions, producers will be under huge pressure, since they do not use efficient technology that is sustainable and costeffective. Martin-Pena et al. (2014) identified main benefits and obstacles of implementing environmental management system in Spanish automotive industry, where Daimler, Ford, General Motors, Nissan, PSA Group, Renault, and Volkswagen, have their plant facilities. Benefits of implementing such kind of a system include improved market position, stakeholder relations and environmental performances with much wider access to environmental technologies. On the other hand, difficulties for companies in Spanish automotive industry are the requirements of the system, the organizational structure and commitment of the human resources (managers and workers), lack of quality environmental information in establishing environmental goals, calculating outcomes and defining proper responsibility in supply chain. Habidin et al. (2015) analyzed the efficiency of environmental sustainability in Malaysian automotive industry, since Toyota and Volkswagen have their facilities in Malaysia. Authors have found the existence of high and very strong relation between economic, environmental and social part of sustainability in Malaysian automotive industry. Zubir et al. (2012) suggested that automotive producers in Malaysia should work on models that could have a greater impact on local communities with achieving all important social goals. Caniels et al. (2013) examined possible drivers for green initiatives in German automotive industry. After very detailed analysis, it was found that supplier capacity and customer requirements are main drivers for implementing sustainable technologies in German automotive industry. As for the relational norms and customer investments, they have statistically significant impact on green initiatives, but the strength of that relation is not so strong. Key for improving sustainable results in German automotive industry are innovations, good cooperation and the existence of demand for cars that do not pollute the environment. Mathivathanan et al. (2018) emphasized on the importance of sustainable supply chain in Indian automotive industry. The expansion of market and improvement of domestic economic power will bring economic benefits, but on the other hand it will bring many environmental problems and unsolved social issues. Therefore, Indian automotive industry starts with transition to sustainable technologies gradually. 


\section{RESEARCH METHODOLOGY}

Automotive industry is a specific kind of industry since it is one of the leading global industries, but it is also one of the biggest polluters in the world. Therefore, study research includes the analysis of the implementation of sustainable development models in global automotive industry for the period 2006 - 2017. The research covers 15 biggest automotive producers in the world, as follows: BMW, Changan, Daimler, Fiat, Ford, General Motors, Honda, Hyundai, Nissan, PSA Group, Renault, SAIC, Suzuki, Toyota and Volkswagen. For the purpose of the research annual and sustainable reports of automotive producers have been used as the basis and the source of quantitative data.

In this paper multiple linear regressions with fixed effects was the main statistic tool that brought the output presented as a panel data. The choice of multiple linear regressions with fixed effects was a result of the existence of cross - section/time series data that required a bit more complex kind of analysis than simple linear regression. For the purpose of the research following variables were used: $R \& D$ costs (RD), environmental costs (EnvCost), costs of materials (MatCost), costs of sale (SaleCost), donations (Social), net profit (Profit) and $\mathrm{CO}_{2}$ emissions $\left(\mathrm{CO}_{2}\right)$. The selection of variables was limited by the availability of data from annual and sustainable reports, since some producers do not provide full data about their activities. In this study, donations, net profit and $\mathrm{CO}_{2}$ emissions, were used as dependent variables, since each of them represent one of the three pillars of sustainable development. All other variables in this research were used as independent variables in order to see if they have any impact on sustainable development policy of automotive producers.

After applying descriptive statistics, which shows minimum, maximum, mean and standard deviation of the variables, correlation between all variables was tested. For the purpose of correlation analysis, Pearson's correlation coefficient and matrix has been used to measure dependency between variables. As was earlier mentioned multiple linear regression model was primary statistical choice for the analysis of 15 world's biggest automotive producers $(I=1, \ldots 15)$.Analysis of adequate datasets off all automotive producers mentioned, was performed for a period time of 12 years, so an adequate regression model was:

$$
y_{i t}=\alpha+x_{i t} \beta+c_{i}+u_{i t}
$$

Where:

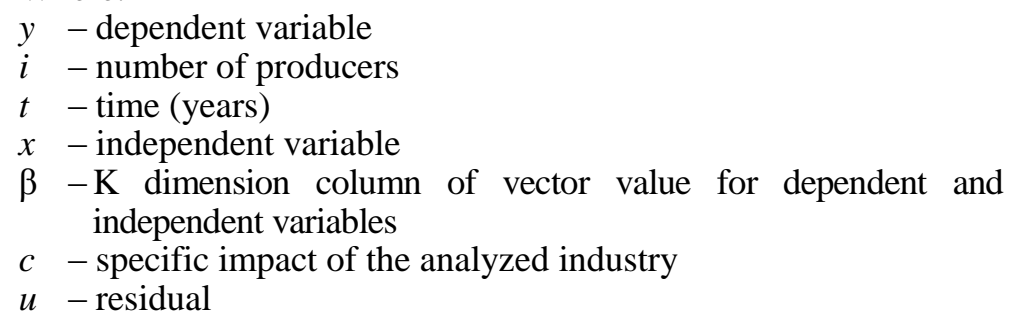


For the purpose of the research, following hypotheses were defined and tested:

H1: Environmental costs have negative impact, while sales increase and material costs decrease have positive impact on net profit of automotive producers.

H2: The increase in material and sales costs will generate higher social contributions of automotive producers.

H3: $R \& D$ and material costs have statistically significant impact on $\mathrm{CO}_{2}$ emissions.

Every of these hypotheses should assist automotive producers to find an appropriate business model that satisfies all aspects of sustainable development concept. This can help automotive producers to think more of their activities that precede production process in order to cut their costs and behave in more preventive manner (Schoeggl et al., 2017; Hirsch, 2018). Green economy model should be the concern of all automotive producers, because it can bring them many long term benefits and make them more recognizable to stakeholders from other industries (Lambert and Davidson, 2013; Nilsson and Nymkvist, 2013).

The model presented by equation 1 rises a question about existence of correlation between residual $\mathrm{u}_{\mathrm{it}}$ and dependent variables, i.e. $\mathrm{E}=($ uit $\mid \mathrm{Xi}, \mathrm{ci})=$ 0 (variables are not correlated) and $\mathrm{E}=($ uit $\mid \mathrm{Xi}$, ci) $\neq 0$ (variables are correlated). This is a consequence of choice between random effect and fixed effect model. For the purpose of analysis, fixed effect model is selected due to specificity of analyzed automotive producer $\mathrm{c}_{i}$ that can make correlation with independent variables. Also, at this type of model specificity of automotive producer is changing through time, which can tell something more about characteristics of industry or specific economic subject with more real observation. Therefore, the fixed effect model is used in the paper.

\section{RESULTS AND DISCUSSION}

Many global companies have started with implementation of sustainable development concept long time ago and they implement sustainable solutions with more or less success. Some of them have defined sustainable strategies, started with the implementation and abandon it after short time. Some of companies never implemented sustainable activities, although they have accepted sustainable development principles. Since automotive producers are considered huge polluters, there was some kind of resistance among them about accepting sustainability development concept (Salvado et al., 2015). So far, all automotive producers have started implementation of sustainable solutions in their businesses and with every new environmental regulation or market change producers are adjusting their sustainable development policy (De Stefano et al., 2016; Iris, 2016). In some cases transition to new technologies implies either production of 
hybrid or electric cars. Production of electric cars is more preferred due to environmental concern, but there still has to be implemented an efficient business model that will cover both economic and environmental dimension of electric car production and purchase (Bohnsack et al., 2014). Statistical analysis in this research should provide answers to questions how far has global automotive industry gone with the implementation of sustainable development principles in the observed period (i.e. from 2006 to 2017), and what could be the future moves of automotive producers in the sustainability area.

Table 1 Descriptive statistics

\begin{tabular}{lcccrr}
\hline Variable & Obs & Mean & Std. Dev. & \multicolumn{1}{c}{ Min } & \multicolumn{1}{c}{ Max } \\
\hline RD & 180 & 3.645818 & 2.557093 & .54 & 13.67 \\
EnvCost & 180 & .7063636 & .7613187 & .09 & 3.31 \\
MatCost & 180 & 93.62382 & 34.94626 & 6.54 & 159.23 \\
SaleCost & 180 & 68.04473 & 48.54989 & 1.28 & 188.59 \\
Social & 180 & 41.7557 & 37.26453 & 6.59 & 214 \\
Profit & 180 & 6.709873 & 4.324555 & -4.7 & 21.88 \\
$\mathrm{CO}_{2}$ & 180 & 6.773818 & 2.198908 & 3.54 & 12.79 \\
\hline \multicolumn{7}{c}{ Source: Authors calculations }
\end{tabular}

Descriptive statistics showed that almost all variables (except for environmental costs) have higher mean value than their standard deviation value, which is good for further analysis. All dependent variables (social donations, net profit and $\mathrm{CO}_{2}$ emissions) also have very high mean values. According to Table 1, the lowest donations from automotive industry were 6.59 million $€$, while highest were 214 million $€$. Automotive producers also had net loss about 4.7 billion of $€$, while their highest net profit was 21.88 billion $€$. Lowest $\mathrm{CO}_{2}$ emissions were 3.54 million tons, while highest emissions were 12.79 million tons.

Table 2 Correlation analysis

\begin{tabular}{|c|c|c|c|c|c|c|c|}
\hline & RD & EnvCost & MatCost & SaleCost & Social & Profit & $\mathrm{CO}_{2}$ \\
\hline RD & 1.000 & & & & & & \\
\hline \multirow[t]{2}{*}{ EnvCost } & $0.3519^{*}$ & & & & & & \\
\hline & 0.0000 & 1.000 & & & & & \\
\hline \multirow[t]{2}{*}{ MatCost } & $0.6482^{*}$ & $0.4074^{*}$ & & & & & \\
\hline & 0.0000 & 0.0000 & 1.000 & & & & \\
\hline \multirow[t]{2}{*}{ SaleCost } & $0.8974^{*}$ & $0.4357^{*}$ & $0.6675^{*}$ & & & & \\
\hline & 0.0000 & 0.0000 & 0.0000 & 1.000 & & & \\
\hline \multirow[t]{2}{*}{ Social } & $0.4243^{*}$ & $0.7073^{*}$ & $0.3957^{*}$ & $0.5425^{*}$ & 1000 & & \\
\hline & 0.0000 & 0.0000 & 0.0000 & 0.0000 & 1.000 & & \\
\hline \multirow[t]{2}{*}{ Profit } & $0.5303^{*}$ & $0.3750^{*}$ & $0.3822^{*}$ & $0.4970^{*}$ & $0.4278^{*}$ & \multirow{2}{*}{1.000} & \\
\hline & 0.0000 & 0.0000 & 0.0000 & 0.0000 & 0.0000 & & \\
\hline \multirow[t]{2}{*}{$\mathrm{CO}_{2}$} & $0.3719^{*}$ & $-0.1901^{*}$ & $-0.2034^{*}$ & $0.2949^{*}$ & $-0.1644^{*}$ & $0.1431^{*}$ & \multirow{2}{*}{1.000} \\
\hline & 0.0000 & 0.0145 & 0.0088 & 0.0001 & 0.0348 & 0.0468 & \\
\hline
\end{tabular}


Donations have the strongest correlation with environmental costs (0.7073), while they have weakest relation with material costs $(0.3967)$. Net profit has the strongest correlation with $R \& D$ costs $(0.5303)$, while their weakest correlation is with environmental costs (0.3750). $\mathrm{CO}_{2}$ emissions have the strongest correlation with $R \& D$ costs $(0.3719)$, while they have the weakest correlation with environmental costs (-0.1901). All dependent variables have statistically significant relations between each other. Among them net profit and donations have the strongest correlation (0.4278), while $\mathrm{CO}_{2}$ emissions and net profit have the weakest correlation (0.1431).

Table 3 Panel data for net profit

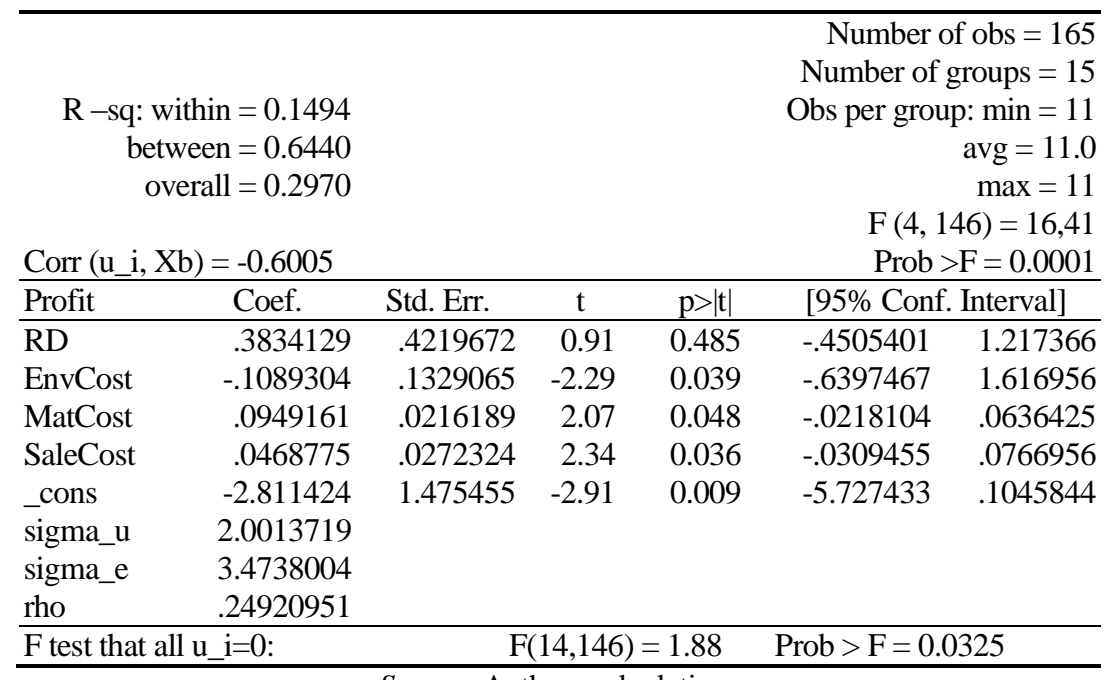

Source: Authors calculations

The analysis first showed that the model indicated statistical significance (since $\mathrm{p}<0,05$ ) with $\mathrm{R}$-square 0,1494 and high correlation coefficient of $-0,6005$. With the increase (reduce) of environmental costs for $1 \%$, the estimated net profit will fall (increase) for 0,108 percentage points. If material costs increase for $1 \%$, the estimated net profit will increase for 0,094 percentage points. Analysis also showed that increase in sales costs for $1 \%$ will raise estimated net profit for 0,046 percentage points.

Based on Table 4, model indicated statistical significance with $\mathrm{R}=$ 0,4245 and correlation coefficient 0,1716 . The analysis showed that only material and sale costs have statistically significant impact on donations (Table 4). When material costs increase for $1 \%$, estimated donations will increase for 0,227 percentage points. As for sales costs, their increase for $1 \%$ will lead to further increase of estimated donations by 0,186 percentage points. This means that improved economic performances will 
produce more donations to local communities and many global projects that target social issues.

Table 4 Panel data for social contributions (donations)

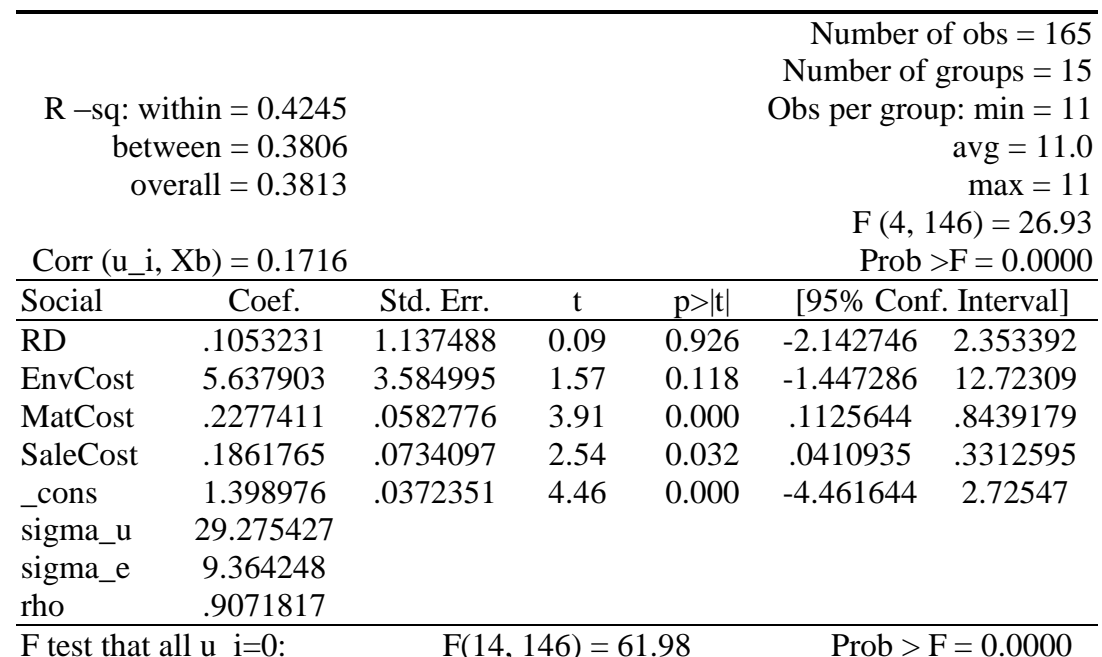

Source: Authors calculations

Table 5 Panel data for $\mathrm{CO}_{2}$ emissions

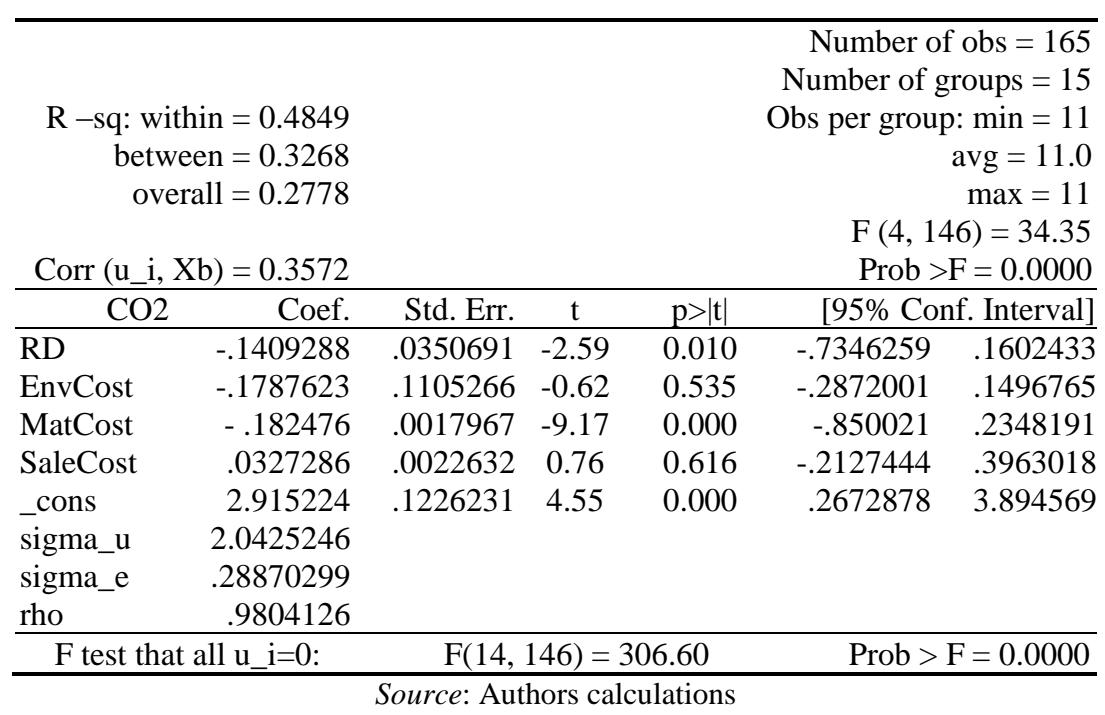

Regression analysis showed statistically significance of the model in case of $\mathrm{CO}_{2}$ emissions with $\mathrm{R}=0,4849$ and correlation coefficient 0,3572 . Also, only R\&D costs and material costs showed that they have statistically 
significant impact on $\mathrm{CO}_{2}$ emissions (table 5). The increase (reduce) in environmental costs for $1 \%$ will reduce (increase) estimated $\mathrm{CO}_{2}$ emissions for 0,140 percentage points. This showed that $R \& D$ activities were effective so far and that they should improve in the future. As for material costs, their increase (reduce) for $1 \%$, estimated $\mathrm{CO}_{2}$ emissions will reduce (increase) for 0,082 percentage points.

\section{CONCLUSION AND RECOMMENDATIONS}

The analysis showed good results of implementing sustainable development activities in global automotive industry. This was confirmed by statistical analysis of $\mathrm{H} 1, \mathrm{H} 2$ and $\mathrm{H} 3$ hypothesis, which were all confirmed. Close relation between the pillars indicates that sustainable development concept was appropriately applied in automotive industry worldwide, but there are possibilities of further improvement in the future. Although material and sale costs go in line with net profit, environmental costs have negative impact on net profit which shows that if automotive producers decide to go with sustainable solutions they need to count on reduced net profit. On the other hand, since higher material and sale costs cause higher net profit, there will be more space for producer's donations to local communities and global projects with social issues. Also, higher investments in R\&D will help reducing $\mathrm{CO}_{2}$ emissions, but higher material costs will remain a problem, so producers have to start with more efficient and sustainable use of materials during the production process. Another problem is that environmental costs do not have any statistically significant impact on $\mathrm{CO}_{2}$ emissions and because of that automotive producers have to make their current environmental plans and strategies adjustable to their environmental goals, with emphasis on constant improvement. This means better planning of the whole life-cycle of vehicles, available funds and appropriate resources management.

Global automotive producers already apply different sustainable development strategies, but they need to work very hard in order to improve sustainability performances. Current results indicate some kind of progress, but that is not enough. Automotive producers should work more on development of sustainable technologies and discover new solutions that will bring them new customers and markets. Corporate sustainable responsibility should become basis of every new policy of automotive producers with clear goals of achieving sustainable goals. Future studies should be oriented towards particular analysis of sustainability development pillars in automotive industry with discovering all problems and obstacles for achieving sustainable development goals. It would be good that future studies analyze economic costs of achieving sustainability goals in all three pillars of sustainable development, which would give a clear view for automotive producers to start with reorganizing their current activities. Analysis about current and the development of new environmentally friendly business 
models in automotive industry would also help many producer to start with sustainable activities more seriously in order to give bigger contribution for solving some of the environmental and social problems in the world.

\section{REFERENCES}

Balkyte, A. \& Tvaronavičiene, M. (2010). Perception of competitiveness in the context of sustainable development: Facets of "sustainable competitiveness".Journal of Business Economics and Management 11(2), 341-365. DOI: 10.3846/jbem. 2010.17

BMW (2006-2017). Annual and Sustainable Value Reports. Munich: BMW.Retrieved from:https://www.bmwgroup.com.

Bohnsack, R., Pinkse, J. \& Kolk, A. (2014). Business models for sustainable technologies: Exploring business model evolution in the case of electric vehicles.Research Policy 43(2), 384-396.DOI: 10.1016/j.respol.2013.10.014

Bostan, I., Onofrei, M., Dascălu, E.D., Fîrțescu, B. \& Toderașcu, C. (2016). Impact of Sustainable Environmental Expenditures Policy on Air Pollution Reduction, During European Integration Framework.Amfiteatru Economic 18(42), 286-302.

Bunzel, W. \& M, Ruhnau, T. (2015). Drivers of Sustainability in the Automotive Industry. In: Denbratt, I., Subic, A. \& Wellnitz, J. (eds.) Sustainable Automotive Technologies. Cham: Springer.

Calabrese, G. (2016).The greening of the automotive industry. London: Palgarve Macmillan.

Calu, A., Negrei, C., Calu, D.A. \& Avram, V. (2015). Reporting of Non-Financial Performance Indicators - a Useful Tool for a Sustainable Marketing Strategy. Amfiteatru Economic 17(40), 977-993.

Caniels, M., Gehrsitz, M. \& Semeijn, D. (2013). Participation of suppliers in greening supply chains: An empirical analysis of German automotive suppliers.Journal of Purchasing and Supply Management 19,134-143. DOI: 10.1016/j.pursup. 2013.02.005

Changan (2006-2017). Annual and CSR Reports. Chungking: Changan.Retrieved from: https://www.globalchangan.com.

Daimler (2006-2017).Annual and Sustainability Reports. Stuttgart: Daimler.Retrieved from:https://www.daimler.com.

De Stefano, M. C., Montes - Sancho, M. J. \& Busch, T. (2016). A natural resource based view of climate change: Innovation challenges in the automobile industry.Journal of Cleaner Production 139, 1436-1448. DOI: 10.1016/j.jclepro. 2016.08.023

Fiat (2006-2017).Annual and Sustainability Reports. Turin: Fiat.Retrieved from:https://www.fcagroup.com.

Ford (2006-2017).Annual and Sustainability Reports. Dearborn: Ford.Retrieved from: https://www.ford.com.

General Motors (2006-2017).Annual and Sustainability Reports. Detroit: General Motors.Retrieved from:https://www.gm.com.

Habidin, N., Zubir, A., Fuzi, N., Latip, N. \& Azman, M. (2015). Sustainable Performance Measures for Malaysian Automotive Industry.World Applied Science Journal 33(6),1017-1024. DOI: 10.5829/idosi.wasj.2015.33.06.257

Hahm, T., Figge, F., Barkemeyer, R. \& Liesten, A. (2009).Sustainable Value in Automobile Manufacturing (2nd edition), Belfast: Queen University. 
Hashmi, A., R. \& Van Biesbroeck, J. (2016). The relationship between market structure and innovations in industry equilibrium: A case study of the global automotive industry. The Review of Economics and Statistics98(1), 192-208. DOI: 10.1162/ Rest_a_00494

Health Effects Institute (2010).Traffic - related pollution: A critical review of the literature on emissions, expenditure and health effects. Boston: Health Effects Institute. Retrieved from:https://pubs.healtheffects.org

Hirsch, S. (2018). Successful in the long run: A Meta - regression analysis of persistent firm profits. Journal of Economic Surveys 32(1), 23-49. DOI: 10.1111/joes.12188

Honda (2006-2017).Annual and Sustainability Reports. Tokyo: Honda. Retrieved from:http://www.world.honda.com

Hyundai (2006-2017).Annual and Sustainability Reports. Seoul: Hyundai. Retrieved from:https://www.hyundai.com.

Iris, D. (2016). Economic targets and loss - aversion in the international environmental cooperation. Journal of Economic Surveys 30(3), 624-648. DOI: 10.1111/joes. 12155

Juniarty, M. \& Ismail, M. (2015). Analyzing sustainability of SMEs in automotive component industry in Benasi regency. Journal of Asian Scientific Research 5(12),522-533.DOI: 10.18488/journal.2/2015.5.12/2.12.522.533

Kushwaha, G. \& Sharma, N. (2015). Green initiatives: A step towards sustainable development and firm's performance in the automobile industry. Journal of Cleaner Technologies, 30, 1-14. DOI: 10.1016/j.jclepro.2015.07.072

Lambert, J. C. \& Davidson, R. A. (2013). Applications of the business model in studies of enterprise success, innovation and classification: An analysis of empirical research from 1996 to 2010. European Management Journal 31(6), 668-681.DOI: 10.1016/j.emj.2012.07.007

Lee, K. H. (2011). Integrating carbon footprint into supply chain management: The case of Hyundai Motor Company (HMC) in the automobile industry. Journal of Cleaner Production 19(11), 1216-1223.DOI: 10.1016/j.jclepro.2011.03.010

Martin - Pena, M., Diaz - Garrido, E. \& Sanchez - Lopez, J. (2014) Analysis of benefits and difficulties associated with firms Environmental Management Systems: The case of the Spanish automotive industry. Journal of Cleaner Production, 70, pp. 220-230. DOI: 10.1016/j.jclepro.2011.03.010

Mathivathanan, D., Kannan, D. \& Noorul Hay, A. (2018). Sustainable supply chain management practices in Indian automotive industry: A multi stakeholder view. Resources, Conservation and Recycling 128, 284-305.

Mayyas, A., Qattawi, A., Omar, M. \& Shan, D. (2012). Design for sustainability in automotive industry: A comprehensive review. Renewable and Sustainable Energy Reviews 16, 1845-1862.DOI: 10.1016/j.rser.2012.01.012

Namakachi, K., Hanaoka, S. \& Kawahara, Y. (2016). Estimation of cost and CO2 emissions with a sustainable cross - border supply chain in the automobile industry: A case study of Thailand and neighboring countries. Transportation Research Part D: Transport and Environment 43, 158-168. DOI: 10.1016/ j.trd.2015.12.018

Nilsson, M. \& Nykvist, B. (2016). Governing the electric vehicle transition - Near term interventions to support a green energy economy. Applied Energy 179, 1360-1371. DOI:10.1016/j.apenergy.2016.03.056

Nissan (2006-2017)Annual and Sustainability Reports. Yokohama: Nissan. Retrieved from:http://www.nissan-global.com

PSA Group (2006-2017). Annual and CSR Reports. Paris: PSA Group. Retrieved from: https://www.groupe-psa.com 
Renault (2006-2017). Annual and CSR Reports. Boulogne Billancourt: Renault. Retrieved from: https://group.renault.com

SAIC (2006-2017). Annual and Sustainability Reports. Shanghai: SAIC. Retrieved from:http://www.saicmotor.com.

Salvado, M. F., Azevedo, S. C., Matias, J.C.O. \& Ferrerira, L. M. (2015). Proposal of a sustainability index for the automotive industry. Sustainability 7(2), 21132144.DOI: $10.3390 /$ su7022113

Schoeggl, J. P., Baumgartner, R. J. \& Hofer, P. (2017). Improving sustainability performance in early phases of product design: A checklist for sustainable product development tested in the automotive industry. Journal of Cleaner Production 140(3), 1602-1617. DOI: 10.1016/j.jclepro.2016.09.195

Suzuki (2006-2017). Annual, CSR and Environmental Report. Hamatsu: Suzuki. Retrieved from: https: www.globalsuzuki.com

Toyota (2006-2017).Annual and Environmental Reports Aichi: Toyota. Retrieved from: https://www.toyota-global.com

Transportation Research Board. (2002). The Congestion Mitigation and Air Quality Improvement Program. Assessing 10 years of experience. Washington: National Academy Press. Retrieved from:http://onlinepubs.trb.org/onlinepubs/sr/sr264.pdf.

Volkswagen (2006-2017). Annual and Sustainability Reports. Wolfsburg: Volkswagen. Retrieved from: https:// www.en.volkswagen.com

Wells, P. (2013). Sustainable business models and the automotive industry: A commentary. IIMB Management Review 16(4), 15-24. DOI: 10.1016/j.iimb. 2013.09.004

Zanello, G., Fu, X., Hohnen, P. \& Ventresca, M. (2016). The creation and diffusion of innovation in developing countries: A systematic literature review. Journal of Economic Surveys 30(5), 884-912. DOI: 10.1111/joes.12126

Zubir, A., Habidin, N., Conding, J., Jaya, N. \& Hashim, S. (2012). The development of sustainable manufacturing practices and sustainable performance in Malaysian automotive industry. Journal of Economics and Sustainable Development 3(7), $130-138$.

\title{
ОДРЖИВИ РАЗВОЈ КАО ПРЕДНОСТ И ПРЕПРЕКА ЗА ГЛОБАЛНУ АУТО-ИНДУСТРИЈУ
}

\author{
Снежана Радукић, Душан Перовић, Марија Петровић Ранђеловић \\ Универзитет у Нишу, Економски факултет, Ниш, Република Србија
}

\section{Резиме}

Изазови који са собом носе климатске промене, уз све чешћу појаву бројних еколошких проблема, утицали су на многобројне профитне и непрофитне организације да своје активности ускладе на начин који је прихватљив са аспекта заштите животне средине. Под утицајем регулативе и захтева екстерних стејкхолдера, многа предузећа која су препозната као загађивачи морала су да промене свој начин пословања. То је у великој мери подразумевало инкорпорирање основних еколошких принципа и усвајање и имплементацију стратегија одрживог развоја на нивоу предузећа. Аутомобилска индустрија представља један од специфичних примера где имплементација политике одрживог развоја истовремено представља како предност тако и препреку за даљи развој предузећа. Предност се огледа у то- 
ме што се произвођачи аутомобила подстичу на иновативне процесе који подразумевају употребу технологија за производњу аутомобила који би мање загађивали животну средину, али и окретање ка неким новим тржиштима где постоји тражња за аутомобилима који не загађују животну средину. Препреке се огледају у виду бројних регулаторних норми које произвођачи аутомобила морају да испуне, али и у виду промене модела пословања који захтева огромне инвестиције.

Имајући у виду да је остварење економских циљева приоритетно за произвођаче аутомобила, имплементација стратегија одрживог развоја у великој мери зависи од економских перформанси свих предузећа у аутомобилској индустрији. Ако се изузме профит, трошкови истраживања и развоја, трошкови набавке сировина (материјала), трошкови продаје и трошкови заштите животне средине имају веома значајну улогу приликом економских анализа пословања 15 највећих произвођача аутомобила у свету. Зато је неопходно узети у обзир све ове трошкове и утврдити меру њиховог утицаја на сва три стуба одрживог развоја представљених преко нето профита, емисија СО2 и издвајања за друштвено одговорно пословање. Анализа је показала да трошкови набавке материјала, трошкови продаје и трошкови заштите животне средине имају статистички значајан утицај на нето профит водећих произвођача аутомобила, док у случају емисија СО2 трошкови истраживања и развоја и трошкови набавке материјала имају статистички значајан утицај. Када су у питању издвајања за друштвено одговорно пословање, резултати истраживања показали су да трошкови набавке материјала и трошкови продаје имају статистички значајан утицај на издвајања произвођача аутомобила за друштвено одговорно пословање. Истраживање је показало да је економски стуб одрживог развоја знатно подложнији утицајима пословних трошкова у односу на еколошки и социјални стуб одрживог развоја. Иако је економски аспект пословања приоритетан, како се све више буду повећавали захтеви стејкхолдера и регулаторних тела за еколошки прихватљивим пословањем, произвођачи аутомобила почеће да посвећују већу пажњу еколошкој и социјалној компоненти пословања. Зато је неопходно да произвођачи аутомобила добро анализирају све предности и препреке које им доноси процес имплементације концепта одрживог развоја и да унапреде своје политике одрживог развоја како би дали већи допринос глобалној борби против климатских промена. 